> Gi respons på artikler gjennom artiklenes kommentarfelt på tidsskriftet.no.

Innleggene publiseres fortløpende på Tidsskriftets nettside og et utvalg

av innleggene publiseres også i papirutgaven i spalten «Brev til redaktøren».

Redaksjonen forbeholder seg retten til å foreta redaksjonelle endringer.

Forfattere av vitenskapelige artikler har tilsvarsrett, jf. Vancouver-gruppens regler.

\section{Re: Akupunktur mot forstoppelse}

I Tidsskriftet nr. 3/2017 beskrives hvordan forskning publisert i Annals of Internal Medicine viser at akupunktur er effektivt mot kronisk forstoppelse (1). Professor Arne Johan Norheim kommenterer forskningen og sier at akupunktur kan være et behandlingsalternativ ved funksjonell obstipasjon. Er det dog støtte for dette i originalartikkelen?

I studien var det ikke akupunktur, men lette elektriske støt via nåler plassert i huden, såkalt elektroakupunktur, som ble utført (2). Studien var ikke blindet. Pasientene ble delt i to grupper. Den ene gruppen fikk elektroakupunktur i det som ble identifisert som akupunkturpunkter, den andre fikk nåler uten elektrisitet $i$ andre punkter. Det var med andre ord to variabler som ble byttet mellom gruppene. Flere studier har de siste årene vist at det ikke spiller noen rolle hvor på kroppen akupunkturnålene plasseres $(3,4)$. Det er derfor rimelig å anta at det er den elektriske stimuleringen som gir effekten som beskrives i artikkelen. Slik transkutan elektrisk stimulering blir ofte beskrevet som akupunktur, men mangler likhetstrekk med klassisk akupunktur, dessuten var nålene tilfeldig plassert på akupunkturpunkter.

Da det med tiden bare blir tydeligere at jo bedre konstruert studier av akupunktur er, desto mindre og nærmere placebo blir effekten. Burde vi ikke da la være å anbefale dette som behandling til våre pasienter?

\section{Niklas S. Westerberg}

n.s.westerberg@studmed.uio.no

Niklas S. Westerberg (f. 1980) er medisin- og forskerlinjestudent ved Universitetet i Oslo og Pediatrisk forskningsinstitutt, Oslo universitetssykehus, Rikshospitalet.

Ingen oppgitte interessekonflikter.

\section{Litteratur}

1. Rashidi K. Akupunktur mot forstoppelse? Tidsskr Nor Legeforen 2017: 137: 186

2. Liu Z, Yan S, Wu J et al. Acupuncture for chronic severe functional constipation: a randomized trial. Ann Intern Med 2016; 165: 761 -9

3. Brinkhaus B, Witt CM, Jena $S$ et al. Acupuncture in patients with chronic low back pain: a randomized controlled trial. Arch Intern Med 2006: 166: 450 -7.

4. Cherkin DC, Sherman KJ, Avins AL et al. A randomized trial comparing acupuncture, simulated acupuncture, and usual care for chronic low back pain. Arch Intern Med 2009; 169: 858-66.

\section{Re: Akupunktur mot forstoppelse}

Som angitt var akupunktørene ikke blindet (1). Det er da sannsynlig at den sparsomme behandlingseffekten i denne studien kan tilskrives observatørskjevhet. Dette er et velkjent svakt punkt i akupunkturstudier.

Studiens størrelse fremheves som et kvalitetsstempel, men feces foredles ikke nødvendigvis av størrelsen.

Bør man bruke mer tid på akupunkturstudier på banale tilstander når det allerede finnes flere behandlingsalternativer?
Jeg vil be om at man stiller se litt mer kritisk til disse akupunkturstudiene sett i lys av hvor få gode studier det finnes på området og at disse ikke viser noen virkning utover placeboeffekten. La oss bruke tid, ressurser og spalteplass på behandlinger som faktisk hjelper.

\section{Damoun Nassehi}

damoun.nassehi@gmail.com

Damoun Nassehi (f. 1979) er allmennlege ved Eigersund kommunale legesenter.

Ingen oppgitte interessekonflikter.

\section{Litteratur}

1. Rashidi K. Akupunktur mot forstoppelse. Tidsskr Nor Legeforen 2017; 137: 186.

\section{Re: Mer til skade enn til gagn - hvor mye skal pasientene vite?}

Informasjonsbrev om forskningsprosjekter kan gi opphav til misforståelser og engstelse, skriver Sofia Olsen og medarbeidere i Tidsskriftet nr. 3/2017, og stiller dermed «spørsmål ved behovet for samtykke eller reservasjonsrett ved studier uten intervensjoner» (1).

Et gammelt ordtak sier at «det man ikke vet har man ikke vondt av». Helsinkideklarasjonen om etiske prinsipper for medisinsk forskning som omfatter mennesker sier noe annet, og det samme gjør helseforskningsloven. Her er det et viktig prinsipp at pasienter skal informeres om forskning på deres helseopplysninger og få anledning til å reservere seg fra å delta. Dette prinsippet følger av forskningsdeltakernes rett til selvbestemmelse. Helsinkideklarasjonen sier også at «Ingen nasjonale eller internasjonale etiske, juridiske eller regulatoriske krav skal begrense eller sette ut av kraft noen av de beskyttelsesmekanismene for forskningsdeltakere som er nedfelt i denne deklarasjonen».

Mennesker er ulike og har ulike behov. For noen kan informasjon føre til misforståelser og engstelse. Løsningen på dette er ikke å la være å informere, men å informere på en bedre måte. Det er forskerens ansvar å gjøre dette og sørge for å være tilgjengelig slik at forskningsdeltagerne kan få svar på eventuelle spørsmål de måtte ha.

\section{Frederik Kragerud Goplen}

frederik.goplen@helse-bergen.no

Frederik Kragerud Goplen (f. 1968) er overlege ved Øre-nese-halsavdelingen, Haukeland universitetssykehus.

Ingen oppgitte interessekonflikter.

\section{Litteratur}

1. Olsen SE, Bretthauer M, Kalager M. Mer til skade enn til gagn - hvor mye skal pasientene vite? Tidsskr Nor Legeforen 2017; 137: 175-6. 